\title{
Diatom complexes of the surface lake sediments in the Indigirka river basin
}

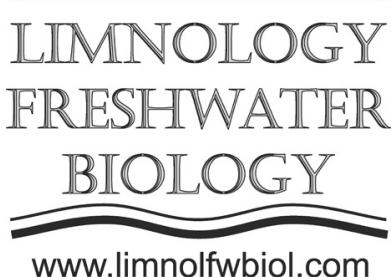

\author{
Levina S.N.*, Pestryakova L.A. \\ North-Eastern Federal University, Belinskogo str., 58, Yakutsk, 677000, Russia
}

\begin{abstract}
This paper provides information about diatomic flora of 42 lakes located in the basin of the Indigirka River. The research material was sampled from surface sediments of lakes of various origin. The field material was collected during expeditions (in 2004, 2006, 2011, and 2017) using standard methods and a set of field equipment. Obtained data can serve as a basis for background monitoring of the ecological state of the environment and water bodies.
\end{abstract}

Keywords: lake, diatoms, Indigirka, Yakutia, Arctic.

\section{Introduction}

In the Northern regions, the landscapes of which are formed in the conditions of the cryolithozone, while reservoirs of various origins are widely distributed. The studied lakes belong to the water-erosion, erosionthermokarst, glacial and thermokarst morphogenetic types. The studied reservoirs are located within the typical tundra, forest tundra, and Northern taiga, as well as in mountainous areas of the high-altitude zone. Most of the research objects are characterized by a very shallow depth ( $<3.12 \mathrm{~m}, 31$ reservoirs), the shape of the mirror is close to round (elongation coefficient (cud) $=$ 1.5-3, 27 reservoirs). Water zone of forest-tundra and typical tundra is very soft, with the total mineralization $0.081 \mathrm{~g} / \mathrm{l}$, a predominance of hydrocarbonate ions and sodium ions, $\mathrm{pH}$ environment of 8.1 , total hardness of 0.6 and with total mineralization of $0.018 \mathrm{~g} / \mathrm{l}$, with a predominance of bicarbonate ions and calcium ions, a neutral reaction medium and total hardness of 0.2 , respectively. The water of lake ecosystems of the Northern taiga is characterized as soft with a total mineralization of $0.123 \mathrm{~g} / \mathrm{l}$, a predominant concentration of bicarbonate ions and magnesium ions, with a neutral $\mathrm{pH}$ and a hardness value of 1.1.

\section{Material and methods}

The material for this work is diatomic complexes of surface sediments of lakes located in different natural zones of the Indigirka River basin and having different origins. The territory of the studied reservoirs is located in the lower Indigirsky lake-thermokarst province of continuous distribution of permafrost within a typical subzone of the tundra zone of North-Eastern Siberia (Nekrasov and Mel'nikov, 1989). In this work, it was also studied Lake Suturuokha which is one of the largest reservoirs in the area.

The field material used to write this paper was collected during previous field operations (in 2004, 2006, 2011, and 2017) using standard methods and a set of field equipment.

\section{Results}

According to the results of the study of 42 lakes in the subarctic tundra, forest tundra and Northern taiga zones of the Indigirka river basin, 257 species (including 4 varieties and forms) of diatoms were registered, which belong to 75 genera, 30 families, 15 orders and three classes. The largest class is the class Bacillariophyceae (93\% of the total sample wealth), with 12 orders, 27 families, 67 genera, 239 species and subspecies registered. The most common family in the studied lakes is Cymbellaceae, which includes 8 genera, Naviculaceae 7 genera, and Stephanodiscaceae and Achnanthidiaceae, which include 6 genera each. The other two classes are significantly inferior to the above class.

Using a percentage of the total populations, the composition of the dominant complexes was revealed: single flaps that make up less than $1 \%$ of their total number in the sample, ordinary ones - from 1 to $5 \%$, subdominants - from 5 to $10 \%$ of the flaps, and subdominants-from $10 \%$. The dominant forms were 32 species, and the subdominant 41 species. Among these species, Staurosira venter is the dominant species in 21 reservoirs with a maximum value of $49.52 \%$, Staurosirella pinnata - in 12 reservoirs with a maximum value of $39.23 \%$, Tabellaria flocculosa - in 11 reservoirs with a maximum value of $47.01 \%$. 


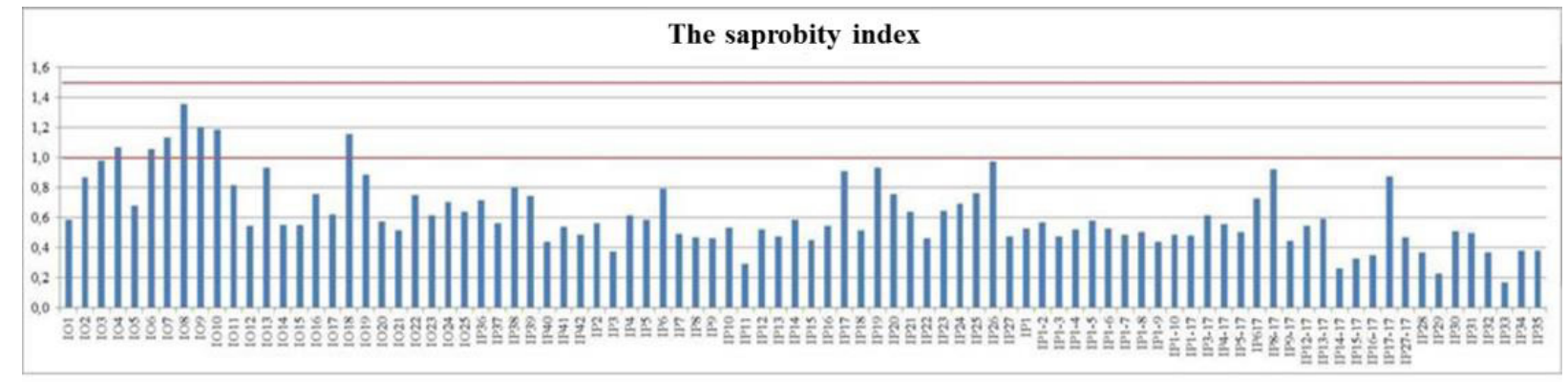

Water quality classes

II class (from 1 to 1,5 - clean)

I class (less than 1 - very clean)

Fig.1. Saprobity indices and the degree of water pollution in lake ecosystems

By number (by the number of flaps per $1 \mathrm{~g}$ of sediment) in the studied reservoirs, the sellaphora pupula species absolutely dominates, which is found in 40 of the 42 lakes studied.

\section{Conclusions}

Since diatoms are indicators of organic pollution of the aquatic environment, the level of organic pollution of the aquatic environment was determined by the Pantle-Buk saprobity index in the Sladechek modification (Sládeček, 1973; Sládeček, 1986) (Fig. 1 ), calculated from the known values of indicator significance and the actual number of individual species and varieties of diatoms (Makrushin, 1974a; Makrushin, 1974b; Barinova and Medvedeva, 1996). Depending on the value of the saprobity index, the level of water contamination was set from very clean ( $S<0.5,1$ st class of water quality, xenosaprobe conditions) to very polluted ( $S>4$, 6th class of water quality, polysaprobe conditions) (GOST 17.1.3.07-82). The studied reservoirs are assigned to the 1st class of water quality (very clean, 69\%) and the 2nd class (clean, 31\%) (Fig. 2.).

The practical significance of the results of this work is the possibility of providing information to stakeholders in the implementation of economic and water management measures in the territory of the Indigirka river basin. Information about diatom flora can serve as a basis for background monitoring of the ecological state of the environment and water bodies.

\section{Acknowledgements}

The study has been carried out in the framework of the project FSRG-2020-0019 founded by the Ministry of Science and Higher Education of the Russian
The reservoirs on the degree of contamination

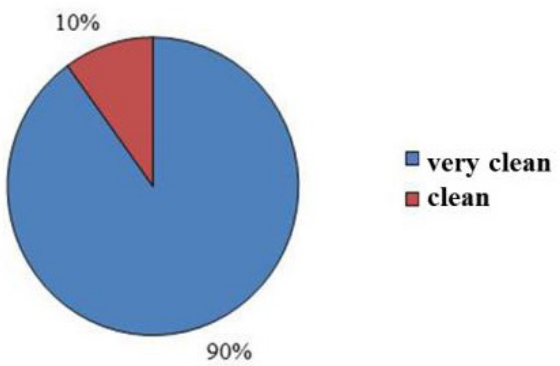

Fig.2. Distribution of diatom complexes by saprobity and degree of contamination in the study area

Federation and RFBR grant No 18-45-140053 r_a founded by the Russian Foundation for Basic Research.

\section{References}

Barinova S.S., Medvedeva L.A. 1996. Atlas vodorosleyindikatorov saprobnosti (rossiyskiy Dal'niy Vostok). Vladivostok: Dal'nauka, (in Russian)

MakrushinA.V.1974a.Bibliograficheskiyukazatel'poteme «Biologicheskiy analiz kachestva vod»s prilozheniyem spiska organizmov-indikatorov zagryazneniya. L.: ZIN AN SSSR. (in Russian)

Makrushin A.V. 1974b. Biologicheskiy analiz kachestva vod. L.: ZIN AN SSSR. (in Russian)

Nekrasov I.A., Mel'nikov P.I. 1989. Merzlotnyye landshafty Yakutii: poyasnitel'naya zapiska k "Merzlotnolandshaftnoy karte Yakutskoy ASSR". Akademiya nauk SSSR, Sibirskoye otd-niye, In-t merzlotovedeniya. (inRussian)

Sládeček V. 1973. System of water quality from the biological point of view. Stuttgart: Schweizerbart,

Sládeček V. 1986. Diatoms as indicators of organic pollution. Acta hydrochimica et hydrobiologica 14(5): 555-566. 